\title{
THE COURSE AND DIDACTIC RESULTS OF MASTER'S STUDIES IN PHYSICAL EDUCATION
}

\author{
Physical education studies
}

\author{
KRYSTYNA BUCHTA
The Josef Pilsudski University of Physical Education in Warsaw, Faculty of Physical Education and Sport in Biala Podlaska, Department of Marketing and Statistics

Mailing address: Krystyna Buchta, Faculty of Physical Education and Sport, 2 Akademicka Street, 21-500 Biała Podlaska, tel.: +48 83 3428784, fax: +48 83 3428800, e-mail: krystyna.buchta@awf-bp.edu.pl

\begin{abstract}
Introduction. The aim of the study was to analyse the effect of Physical Education (PE) studies at the Faculty of Physical Education and Sport (FPE\&S) of the University of Physical Education (UPE) in Warsaw. Material and methods. The study was carried out among the students and graduates of two unified education cycles by means of the documents analysis and the diagnostic poll method with the use of a posted questionnaire. The analysis encompassed the level of preparation for undertaking the studies, academic merits, sport achievements, other experience gained by the examined in the course of the studies and the "output effect" in the form of gained competences. Results. As a result of the study, it was established that the PE studies were undertaken mostly by physically well-prepared graduates of secondary schools whose level of theoretical knowledge was quite low. In the course of the studies, the examined scored average academic merits. The studies constituted for them an opportunity to gain new competences, mainly in the field of physical education. Sporadically, students' activities were directed at educational, organisational and social spheres. Conclusions. In the light of the obtained results, amendments in the national curriculum and changes in physical education teaching methodology seem crucial. Apart from gaining competences pertaining to a particular graduate's profile, development of creative skills, and shaping the proper attitude and behaviour seem vital.
\end{abstract}

Key words: students, physical education, educational process effects, graduate's competences

\section{Introduction}

Both political changes and globalisation put ever higher demands on higher education system. Educational system openness towards the society, labour economics and international educational space are expected [1].

In this situation, a modern institution of higher education, by the development of proper conditions, ought to effectively influence students' personalities, taking care of their further intellectual, professional and public growth [2]. Apart from gaining competences pertaining to a particular graduate's profile, it is vital to develop creative skills and to form proper attitude and behaviour $[3,4,5,6]$.

The aim of the study was to analyse the selected effects of the educational process at unified Physical Education Studies at FPE\&S in Biala Podlaska. The driving force behind the study was the change in the educational process from the unified Masters studies into two-tier university studies and the necessity of evaluation of the institution's educational achievements.

\section{Material and methods}

The study was carried out on 314 students of 4.5 year's unified Masters studies at FPE\&S in Biala Podlaska constituting two consecutive full-time courses of 2002/2003-
2006/2007 (N=144) and 2003/2004-2007/2008 (N=170). Sampling was purposive and exhaustive because the study encompassed all students who graduated within the allotted timeframe.

The majority of the examined were males $(78 \%)$ and city-dwellers $(68 \%)$. The graduates of general upper secondary schools constituted $59 \%$ of the examined.

The study was carried out by means of the university's documents analysis and the diagnostic poll method with the use of a posted questionnaire. The documents' analysis enabled the evaluation of accepted candidates on the basis of the qualifying process (the level of physical fitness, interview result, general certificate of secondary education) and the course and effects of studies (academic merits grade point average, undertaken activity forms, other achievements documented in the diploma supplements).

The results of such analysis were supplemented with the results of the poll carried out among 140 respondents, graduates of the educational cycles. For the purpose of the present study, the examined opinions referring to the quality of education measured with the self-assessment of knowledge and skills connected with the particular educational profile and other selected competences gained during studies were utilised.

Statistical analysis of the data was carried out in Statsoft 6.0 Statistica. In order to establish the level of influ- 
ence of the particular variables on effects of studying, the multivariate regression analysis in the stepwise scenario. Factor analysis with Varimax rotation was also utilised, which allowed to determine the graduate's profile in terms of relevance $\mathrm{p}<0.05$.

Keeping with the concept of the research, answers to the following questions were looked for:

1. What level of readiness towards undertaking of the studies the examined exhibited?

2. What results of studying did the examined gain during their studies?

3. What kind of activities did the examined undertake during their studies?

4. What factors determined the results of studying?

5. How did the graduates evaluate the competences gained during their studies?

In accordance with the definitions put forward by the European Parliament and the Council of the European Union [7], for the purpose of the study the following definition of "the effects of studying" was embraced - "determining what a student knows, understands and is able to do after completing the educational process which is seen in the categories of knowledge, skills and competences" where "knowledge" was defined as "the result of acquiring information through learning" and "skills" denote "the ability to implement knowledge and use know-how in order to execute tasks and solve problems". "Competences", in the context of European Qualification Framework, are described as "a proven ability to implement knowledge, skills, personal, social or methodological capacity displayed in work or learning, in professional career or personal life".

\section{Results}

\section{Candidate's quality}

Due to the fact that reaching the particular results of education requires the possession of suitable "input" resources, the criteria and results of the qualifying process were evaluated.

The selection process for Physical Education studies, which is inseparably connected with the educational model functioning at PE higher education institutions, is based on physical fitness and intellectual criteria. The essential requirement for application, in the period taken into account for the study, was the possession of general certificate of secondary education and adequate health. The positive result of the qualifying process was the success factor. The qualifying process for the full-time studies consisted of: physical fitness evaluation comprising three sport disciplines (choice of gymnastics, athletics, team sports (TS) and swimming -60 points max, 20 points per discipline), interview (15 points), grades from the certificate of education (45 points), licences in the field of physical education (10 points). The final result of the qualifying process was determined by the sum of points obtained and the position in the ranking.
Due to the diversity of the evaluation criteria of the qualifying process individual components, when examining the level of the examined readiness towards undertaking the studies, success indicators which were then related to the maximum number of points and then expressed in percent, were taken into account. Based on such indicators, the analysis of the qualifying process indicated that the best results were gained in the interview (88\% success rate). It is noteworthy that the interview, evaluating the applicant's general knowledge, intellectual agility and ability to express oneself on the subject of physical education, was harder for the graduates of general upper secondary schools $(87 \%$ success rate) than for the graduates of vocational secondary schools (91\%).

High level of physical fitness was also observed $(75 \%$ of the maximum number of points), highest in the field of team sports $(84 \%)$, lowest in the field of athletics $(67 \%)$. The lowest results were obtained in terms of intellectual readiness measured by grades on the general certificate of secondary education (mere $38 \%$ of the maximum number of points) (Fig. 1).

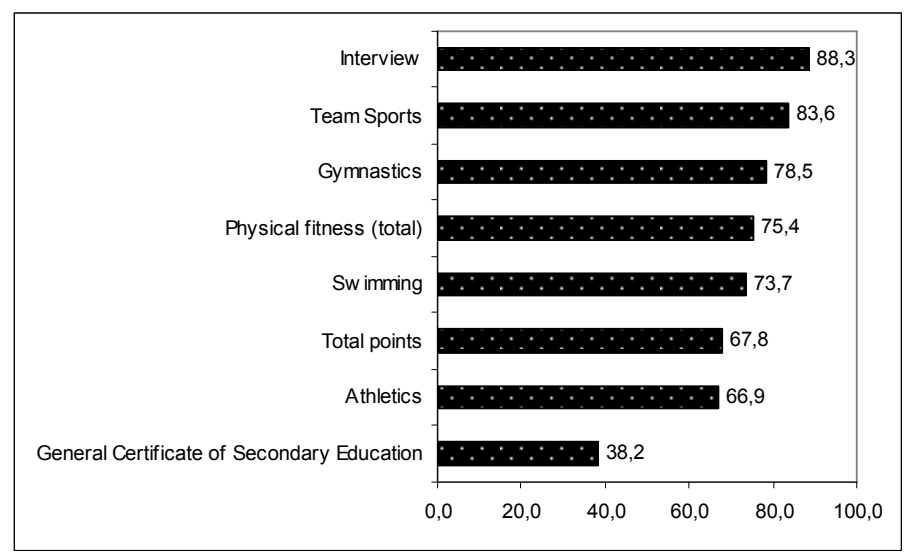

* - the result obtained in relation to the maximum number of points

Figure 1. The results of the qualifying process - success indicators* $(\%)$

A more detailed analysis of the results of the qualifying process conducted with the use of socio-demographic features characterising the examined indicated that male applicants displayed a higher level of physical fitness (except TS) than female applicants. Moreover, students living in cities obtained better TS and swimming results and scored higher in physical fitness that their colleagues coming from the country.

\section{Internal education effectiveness and its conditions}

The analysis of the internal education effectiveness was carried out on the basis of arithmetic mean of the results obtained in the consecutive years of the studies.

In the course of the analysis it was established that the examined displayed average level because the grade point average in the whole educational cycle equalled 3.7 - be- 
ginning with 3.53 in the first year of the studies ending with 3.93 in the fourth year. Only 1 in 11 students of the first year and 1 out of 3 students of the fourth year achieved grade point average above 4 (Fig. 2). Diversification of the studying effects in relation to sex - female students obtained higher grades - grade point average on the general certificate of secondary education (positive correlation) and the type of school graduated from were noted. Graduates of general upper secondary schools obtained higher grades than those of secondary vocational schools (grade point average from $1^{\text {st }}, 3^{\text {rd }}$ year of studies and general grade pint average - statistically vital differences).

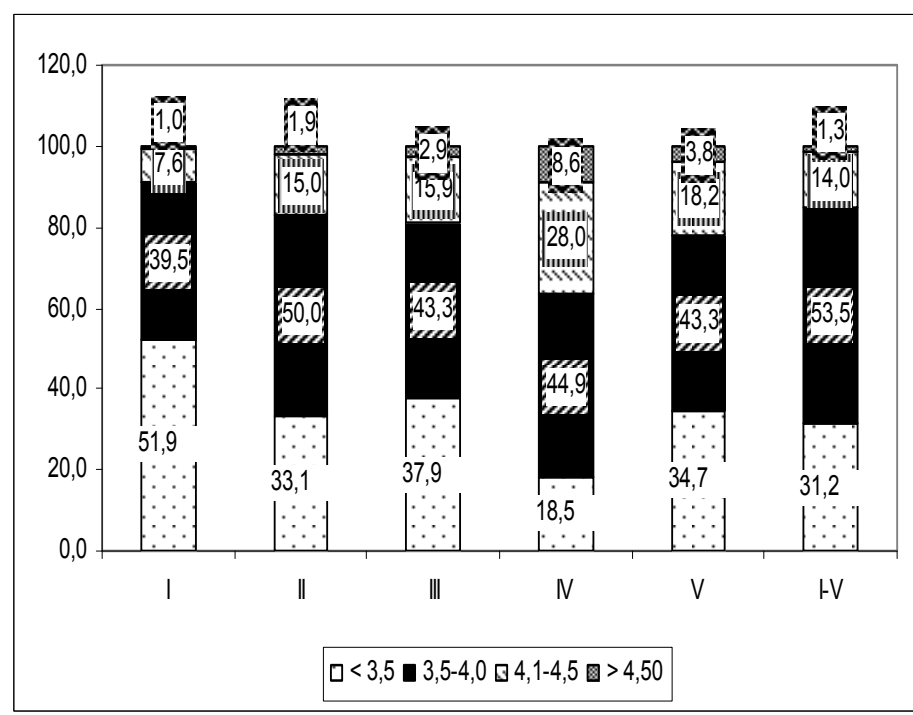

Figure 2. Grades in consecutive years of studies (\%, N=314)

Further data analysis was carried out by means of multiple regression method. The type of stepwise regression utilised in the study allowed for indicating independent variables which influenced the studying effects the most eliminating at the same time false cross-loadings with the studying results (redundancy) [8]. Standardized betas values, defining the level of influence of each variable on academic merits, indicated mainly the grades on the general certificate of secondary education as the relatively best predictor of success rate in the studies. (Tab. 1). In addition, the final result of the qualifying process (total number of points) influenced largely only the fourth year studying effects. Sex (except first year students) and the type of school graduated from (only freshmen students), in turn, among the socio-demographic variables, turned out to have essential influence on the studying effects. Variables in the regression model accounted for 15\% (in the second year students) up to $35 \%$ (third year students) of variances in the studying effects.
Table 1. The results of studying determinants - regression analysis results*

\begin{tabular}{|l|l|l|l|l|l|l|}
\hline Independent variables & I year & II year & III year & IV year & V year & $\begin{array}{c}\text { Grade } \\
\text { point } \\
\text { average } \\
\text { I-V }\end{array}$ \\
\hline $\begin{array}{l}\text { General Certificate of Secondary } \\
\text { Education } \\
\text { Entry exam (points total) } \\
\text { Secondary School Typ** } \\
\text { (Genera Upper Secondary } \\
\text { School=1) } \\
\text { Sex }\end{array}$ & 0.401 & 0.316 & 0.343 & & 0.281 & 0.350 \\
\hline $\begin{array}{l}\text { The coefficient of determination } \\
\mathrm{R}^{* *} 100 \%\end{array}$ & 19.1 & 15.4 & 34.6 & 18.0 & 16.5 & 19.5 \\
\hline
\end{tabular}

\section{Other achievements and activities}

A graduate of PE studies is a specialist who is required to be comprehensively educated and possess versatile personality traits but also display particular attitude and skills. When examining the effects of the education, attention was also turned to other, complementary to knowledge and skills, competences making the professional and social functioning easier.

The results of the research showed that in the course of the studies, students became involved in various types of activities, mainly in the field of physical education, directing themselves chiefly at obtaining certificates for sport instructors (78\%). Graduates of general secondary schools were more active in this respect $(83 \%)$ than those from secondary vocational schools (70\%). In addition, among the less popular activities was involvement in the Academic Sports Association - UPE - 1 out of 7 students became involved. Activity in the scientific field was also relatively low -1 out of 20 students became involved in the activities of science clubs, and 1 out of 11 students was studying at two faculties at the same time. Additional courses, in turn, mainly camp counsellors of children and youths holiday camps, or student practice outside the curriculum were undertaken by 1 out of 8 students in the examined period (Fig. 3).

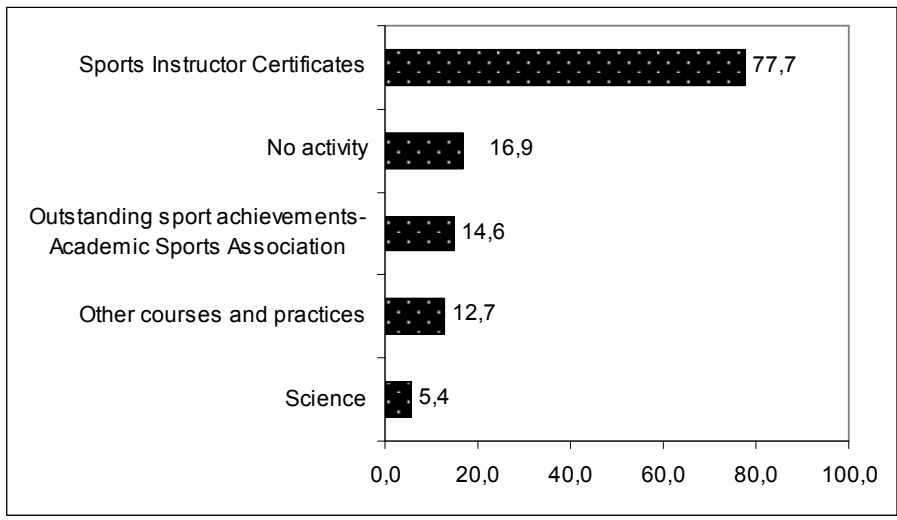

Figure 3. Forms of activity during studies (\%) 
The quality of education as evaluated by the graduates

Assuming that one of the main duties of a modern higher education institution is to prepare a graduate to professional career, the study also takes into account the subjective opinions of former students who responded to poll statistical surveys. The respondents evaluated the level of knowledge and skills gained during their studies in a 1 to 5 scale.

In order to arrange the opinions on the competences possessed, a factor analysis with Varimax rotation was carried out. As a result of the analysis, two independent factors were established. The first factor refers to the competences connected with the educational profile and takes into account elements such as: readiness towards socioorganisational activity, educational work and the level of theoretical knowledge acquired. The second factor refers to some general abilities. The strongest stress, in the latter factor, was placed on becoming computer proficient, knowledge of foreign languages and skill allowing one to become self-employed (Tab. 2).

Table 2. Graduates' competences seen through factor analysis results*

\begin{tabular}{|l|c|c|}
\hline \multicolumn{1}{|c|}{ Competences evaluated } & Factor 1 & Factor 2 \\
\hline Socio-organisational preparation to work & $\mathbf{0 . 7 8 4}$ & 0.247 \\
Theoretical knowledge & $\mathbf{0 . 7 6 5}$ & -0.124 \\
Educational work preparation & $\mathbf{0 . 7 0 7}$ & 0.198 \\
Team management & $\mathbf{0 . 6 2 5}$ & 0.309 \\
Self-studying preparation & $\mathbf{0 . 5 5 9}$ & 0.232 \\
\hline Computer proficiency & 0.304 & $\mathbf{0 . 6 8 9}$ \\
Knowledge of foreing languages & 0.394 & $\mathbf{0 . 6 7 8}$ \\
Self-employment readiness & 0.283 & $\mathbf{0 . 6 6 6}$ \\
Practical skills & 0.248 & -0.467 \\
\hline Explained variation (\%) & 31.0 & 20.7 \\
\hline
\end{tabular}

* - Varimax method; the strongest factors in bold

It is noteworthy that, in accordance with the selfassessment of the examined, the directional competences included in the first factor were assessed as high (arithmetic mean for 1-5 scale; 3.5-4.1) but the components of the second factor were assesses as very low. In this group, becoming computer proficient ranked the highest, nevertheless with the lowest score of 3.3 points. Foreign language skills and readiness to become self-employed ranked as insufficient.

In order to supplement the information on becoming proficient in the selected fields and skills, open questions, which asked to identify methods of improving the quality of education as regards the requirements of the labour market were posed. Respondents' observations addressed towards the institution regarded mainly the necessity to pay close attention to the practical preparation towards professional life, enabling students to gain a greater num- ber of cheaper or free-of-charge certificates for sports instructors ( $14 \%$ of the observations each), additional foreign languages courses $(7 \%)$, driver's license courses, career and preparation to become self-employed counselling $(4 \%$ each).

Graduates employed in the educational system stressed the insufficient preparation towards a real-life work in certain schools greatly diverging from the stereotypes set in the university conditions. There were also signals indicating the necessity of better preparation towards educational work, especially with the difficult youth.

The response pattern as regards the question on satisfaction ensuing from the choice of the educational path and a declaration regarding re-entering the same type of studies, seem to be a synthetic indicator defining the attitude of graduates towards their Alma Mater, and at the same time an indicator of the quality of education [9]. As displayed by the analysis of the graduates' answers, close to $60 \%$ of the respondents were very satisfied, and 1 out of 3 was rather satisfied with undertaking studies at FPE\&S in Biala Podlaska. Moreover, the majority of the respondents declared willingness to re-enter the same type of studies (90\%) with the simultaneous, very low percentage of extreme opinions (slightly more than $1 \%$ of the respondents).

\section{Discussion}

As regards the result of educational influence, on the basis of formal results of studying, it was determined that the majority of students obtained average academic merits on the consecutive levels of education. The analyses showed that such results were largely determined by the examined level of readiness to undertake the studies. Relatively high level of physical fitness at the beginning of studies allowed the majority of the examined to graduate within the curricular timeframe. However, the low level of theoretical preparation, which was reflected in grades on the general certificate of secondary education, enabled only average results of the studies to be achieved.

The diagnosis of internal educational effects was complemented with the evaluation of the examined activeness, which as it turned out, was directed mainly at gaining additional sports qualifications. At the same time, with the relatively large involvement in such one sided activeness, the examined exhibited relatively low involvement in the scientific or socio-organisational field, which was indicated in the previous research carried out among students of PE $[10,11]$. The phenomenon of students' relatively low activity in these spheres has got a greater range going beyond the FPE\&S environment. The underlying cause of the phenomenon is deemed to be the pragmatic lifestyle of the contemporary youth [12]. When studies and gaining additional professional competences consume a considerable portion of students' time, there seems to be little time and space left for other activities. Meanwhile, in the light of 
theoretical deliberations upon a candidate, student and a graduate of a PE higher education institution, a comprehensively active personality seems the most desirable [6, 13]. Taking the perspective of the graduate's future career, preparation towards taking an active part in social life, next to expert knowledge and the ability to implement it in practice, constitutes a crucial indicator of his or her quality.

Therefore, assuming that efficient functioning of the contemporary society depends on whether education develops proper and required attitudes, initiatives and resourcefulness [14], it is essential to revise and update the curriculum and methodology of the educational process. In accordance with the stipulations of the Bologna Process, a change in the teaching paradigm from traditional, teacher and knowledge transmission oriented into student, an entity actively participating in the process, oriented as a necessity [15]. However, the system of studying based in a greater extent on student's self-study requires the preparation of proper activity - stimulating conditions and learning - fostering environment, e.g. greater flexibility and educational individualization. This is also connected with the necessity of securing suitable financial resources, prolonging the working hours of libraries, appropriate number of well-equipped places in reading-rooms (including computer access) and also greater availability of the teaching staff (self-study supervised by teacher-mentors). On the student part, in turn, a greater involvement in the learning process and higher degree of responsibility for shaping one's own career are expected.

Considering the effects of studying from the output parameters perspective i.e. graduates and their competences acknowledged by their degree and the diploma, it must be stated that, despite the examined environmental and educational diversification upon undertaking higher education, a quite homogenous group of people completed their studies. The group evaluated, their gained intellectual and fitness competences as good. Therefore, it seems that the university and the teaching process accomplish not only the educational, but also compensational functions providing the youth with the opportunity to graduate and consequently undertake the trained profession.

Taking the output approach towards the teaching process, where the quality of the process is seen as reflected in the quality of the graduate, one ought to pay attention to the insufficient preparation in the field of some general skills and the reported need for a better preparation towards the professional career voiced in the examined self-assessment. In order to provide the graduate with effectiveness, the higher education institution ought to supply the student not only with knowledge, but should also teach how to put the knowledge into practice and how to shape and gain competences. At the same time, the development of the practical skills must not occur at the expense of the reliable and extensive knowledge constituting the basis for further supplementation, perfection and adaptation towards the ever-changing requirements of the labour market $[5,16]$. In the world where, very often, graduates execute their socioprofessional roles in various spheres of activity, also outside PE, general education has an advantage over specialist education. General competences increase flexibility and improve the ability to quickly adapt to new conditions $[17,18]$.

To conclude, it should be noted that the results of the present study, yet again, verified the thesis on the usefulness of pedagogic methods of selection of applicants for PE studies, which presuppose the fact that a better student of a lesser school will achieve better results at a school with higher standards of education [13]. At the same time, low merits on the general certificate of secondary education confirm previous suppositions claiming that PE studies are chosen by less successful graduates of secondary schools [19], which translates itself into the studying effects gained by these graduates during their university studies. In this case, attempts at adjusting the educational process to students' real abilities seem justified. Simultaneously, in relation to the growing expectations as regards graduates of PE higher education institutions and their competences crucial to successful execution of PE tasks, the problem still stands: Is it at all possible, in today's demographic low and strong competition on the educational market, to select people who, in accordance with the teaching model present at PE universities, will be able to meet such high social expectations?

The implemented research methods do not allow for statistical inferences in terms of the issue studied. However, they do enable highlighting the main tendencies and regularities as regards the effects of studying at unified PE studies.

\section{Conclusions}

1. PE studies were undertaken mostly by graduates of secondary schools who were rather physically fit, displaying however quite low level of theoretical knowledge.

2. The majority of the examined achieved average academic merits.

3. In the course of studies, the examined exhibited large interest in acquiring additional professional competences, but displayed low interest in scientific activities.

4. As the analyses showed, the arithmetic means taken from students grades were mainly determined by the grades on the general certificate of secondary education and the examined sex.

5. According to the graduates' self-assessment, knowledge and skills acquired during studies were their advantages, while general competences were regarded as their weakness. 


\section{Acknowledgements}

The research was accomplished within the framework of research project of Faculty of Physical Education and Sport in Biała Podlaska, Josef Pilsudski University of Physical Education in Warsaw - BW.III/29 - financed by the Ministry of Science and Higher Education.

\section{Literature}

1. Szuwarzyński, A. (2006). DEA method of higher education institutions' didactic effectiveness assessment. Nauka i Szkolnictwo Wyższe 28, 78-88. [in Polish]

2. Szczepański, S. (2007). The Effects of Studying at Opole University of Technology from the Perspective of Students' Self-assessment. Opole: Politechnika Opolska. [in Polish]

3. Białecki, I. (2006). Competences vs. politics regarding education and labour market. Nauka i Szkolnictwo Wyższe 2, 97-107. [in Polish]

4. Bochenek, A. \& Cieśliński R. (2007). Teacher competences in pedagogic literature. Przeglad Naukowy Kultury Fizycznej Uniwersytetu Rzeszowskiego 1, 55-61. [in Polish]

5. Orczykowska, A. (2006). Higher education vs. Labour markets requirements. Nauka i Szkolnictwo Wyższe 2, 49-62. [in Polish]

6. Żukowska, Z. (1997). The analysis of professional aptitude of PE universities graduates In J. Kuźma \& H. Kosętka (Eds.), Psycho-pedagogic training of teachers (pp. 113-125). Kraków: Wyż. Szk. Pedag. [in Polish]

7. The European Parliament's and the Council's instructions regarding the European framework for learning throughout one's life from $23^{\text {rd }}$ April 2008. Journal of Laws no. 111, item 4, from 6 $6^{\text {th }}$ May 2008.

8. Konarzewski, K. (2000). How to Conduct Research in Education. Practical Methodology. Warsaw: WSiP S.A. [in Polish]

9. Kochanowski, J. (2008). Communicative (polylogic) model of quality management in higher education institution. Nauka i Szkolnictwo Wyższe 1, 85-98. [in Polish]

10. Buchta, K. \& Burzyński W.J. (2008). Institutional and environmental conditions of the academic youth activieness. In W. Muszyński (Ed.), "Time will soothe us?" The quality of life and free time in the contemoorary society (pp. 215-224). Toruń: Publ. Adam Marszałek. [in Polish]

11. Jarmuła-Kliś, T. (1996). The Students of the University of Physical Education in Changing Social Reality. Kraków: Wydawnictwa Monograficzne AWF Kraków, 69. [in Polish]

12. Wasielewski, K. (2006). Social diversification of the university. The country and the metropolitan youth at the Nicolaus Copernicus University in Torun. Studia Socjologiczne 1, 119-154. [in Polish]

13. Grabowski, H. (1992). Pedagogic kaleidoscope. Kultura Fizyczna 1-2, 12-15. [in Polish]

14. Denek, K. (2005). The Polish education system in the framework of the European education. Wychowanie Fizyczne i Zdrowotne 11, 4-6. [in Polish]

15. Chełmecki, B. (2007). The education of PE teachers from the perspective of the Bologna Process. In J. Nowocień (Ed.), Socio-educational Aspects of the Contemporary Sport and Olympism. Patriotic Education by Sport (pp. 180-185). Warsaw: AWF, PAOL, Fundacja Centrum Edukacji Olimpijskiej. [in Polish]

16. Bielski, J. (2001). The education of teachers in modern educational reality. Wych. Fiz. Sport 2, 231-240. [in Polish]

17. Allen, J. \& Der Velden R. (2007). The flexible professional in the knowledge society. General results of the REFLEX project. The Netherlands: Research Centre for Education and the Labor Market, Maastricht University, Maastricht.

18. Lamo, A., Messina J. \& Wasmer E. (2006). Are Specific Skills an Obstacle for Labor Market Adjustment. Theory and Practice of an Aplication to EU Enlargement, European Central Bank, Working Paper Series, 585.

19. Biniakiewicz, B. (1994). The Education, Profession and Work of Motor Rehabilitation Workers with Master's Degree. Poznań: Monografie AWF Poznań, 314. [in Polish]

20. Szklarczyk, S., Gabryś T. \& Szade D. (1995). The structure of PE studies candidates readiness as regards general athletic fitness. Zeszyty Metodyczno-Naukowe AWF Katowice 7, 59-63. [in Polish]

Submitted: July 12, 2010

Accepted: October 12, 2010 